\title{
Histiocitoma fibroso maligno de orofaringe. Resección y reconstrucción con colgajo fasciocutáneo radial
}

\author{
Malignant oropharyngeal fibrous histiocytoma. Resection and radial \\ reconstruction with fasciocutaneous flap
}

\author{
L. García Monleón', J. Acero Sanz², Á. del Amo Fernández de Velascoํ', S. Ochandiano Caicoya², \\ J. López de Atalaya2, C. Navarro Vila
}

Resumen: El histiocitoma fibroso maligno se reconoce como el sarcoma de tejidos blandos más frecuente de la edad adulta, aunque su localización en faringe no es usual habiéndose recogido en la literatura científica tan solo 6 casos en esta localización. Presentamos el caso de un paciente con un histiocitoma fibroso maligno en orofaringe de gran tamaño, al que se le realizó una resección con amplios márgenes y la reconstrucción del defecto con un colgajo fasciocutáneo radial. Discutiremos a raíz del caso la epidemiología, manifestaciones clínicas, incidencia de metástasis, histopatología, factores pronósticos y tratamiento de este tipo de tumores.

Palabras clave: Histiocitoma fibroso maligno; Maxilofacial; Cabeza y cueIlo; Orofaringe; Reconstrucción; Colgajo radial.

Recibido: 29.11 .06

Aceptado: 14.01 .08
Abstract: Malignant fibrous histiocytoma is recognized as the most common soft-tissue sarcoma in adults, although its location in the pharynx is unusual. Only 6 cases of the pharynx have been reported in the scientific literature. We report the case of a patient with a large malignant fibrous histiocytoma in the oropharynx. The tumor was resected with generous margins and the defect was reconstructed with a radial fasciocutaneous flap. The epidemiology, clinical manifestations, incidence of metastases, histopathology, prognostic factors and treatment of malignant fibrous histiocytoma are discussed in relation to this case.

Key words: Malignant fibrous histiocytoma; Maxillofacial; Head and neck; Oropharynx; Reconstruction; Radial flap.

\footnotetext{
1 Médico Residente.

2 Médico Adjunto.

3 Jefe de Servicio.

Servicio de Cirugía Oral y Maxilofacial.

Hospital General Universitario Gregorio Marañón. Madrid, España
}

\section{Correspondencia:}

Laura García Monleón

Calle Antonio Zapata, $n^{\circ} 14,2^{\circ} \mathrm{B}$

28002 Madrid, España

Email: lauragmonleon@gmail.com 


\section{Introducción}

El fibrohistiocitoma maligno fue descrito por O'Brien y Stout en 1964, 1 y desde entonces es reconocido como el sarcoma de tejidos blandos más frecuente en la edad adulta. Es una neoplasia definida histopatológicamente por una proliferación mesenquimal de células histiocitarias y de fibroblastos que siguen varios patrones de crecimiento. El HFM debe ser diferenciado de otras neoplasias que también exhiben un importante pleomorfismo como el liposarcoma pleomórfico, rabdomiosarcoma pleomórfico, carcinoma pleomórfico y leiomiosarcoma. 2,3

Se localiza más frecuentemente en las extremidades, retroperitoneo y cavidad abdominal, siendo su localización en cabeza y cuello tan solo el $1-7 \%$ de los casos. 2,4-6 Raramente se localiza en los tejidos blandos de la cavidad oral y en muy pocos casos se observa su localización en orofaringe, como en el caso que nos ocupa. Presentamos, debido a la rareza de su localización e implicaciones de la misma, un nuevo caso de histiocitoma fibroso maligno afectando el paladar blando y pared lateral del orofaringe. Revisamos la literatura a propósito de este caso.

\section{Caso clínico}

Presentamos el caso de un varón de 54 años que acude a nuestra consulta por disfagia, dislalia y sensación de cuerpo extraño en cavidad oral de 2 meses de evolución. El paciente era fumador

Figura 2. TC preoperatoria donde se observa la gran masa pediculada a paladar blando que obstruye la luz de la orofaringe. Figure 2. Preoperative CAT showing a large pediculated mass of the soft palate that obstructs the oropharynx.
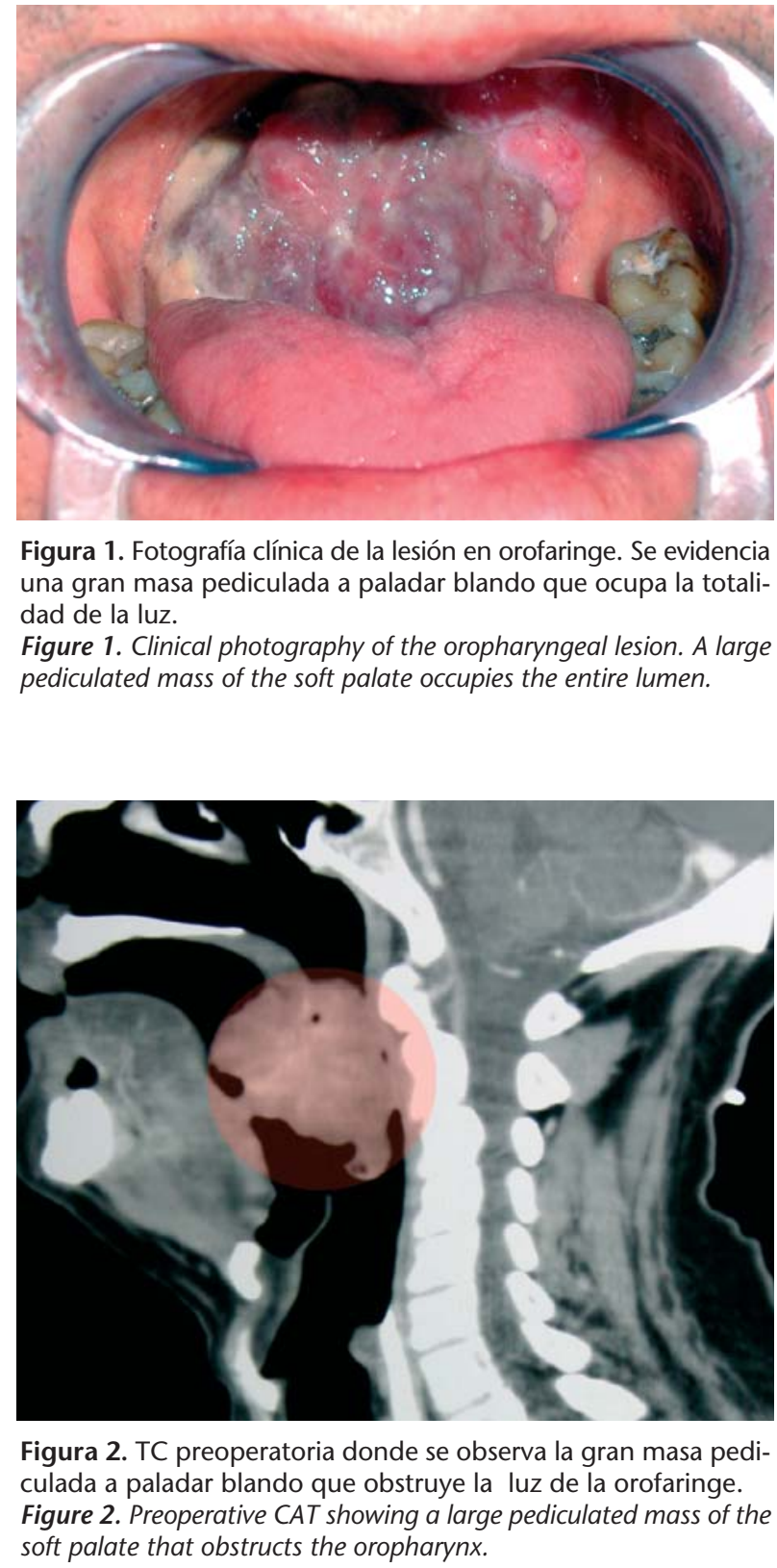

Figura 1. Fotografía clínica de la lesión en orofaringe. Se evidencia una gran masa pediculada a paladar blando que ocupa la totalidad de la luz.

Figure 1. Clinical photography of the oropharyngeal lesion. A large pediculated mass of the soft palate occupies the entire lumen.

\section{Introduction}

O'Brien and Stout 1 described malignant fibrohistiocytoma in 1964. Since then, it has been recognized as the most frequent sarcoma of soft tissues in adults. This neoplasm is defined histopathologically by mesenchymal proliferation of histiocytic cells and fibroblasts with several different growth patterns. MFH must be differentiated from other neoplasms that exhibit marked pleomorphism, such as pleomorphic liposarcoma, pleomorphic rhabdomyosarcoma, pleomorphic carcinoma, and leiomyosarcoma. ${ }^{2,3}$ It is located most frequently in the limbs, retroperitoneum and abdominal cavity, occurring in the head and neck in only $1-7 \%$ of cases. ${ }^{2,4-6}$ It is rarely located in the soft tissues of the oral cavity and very few cases occur in the orophar$y n x$, as in our present case. Due to its exceptional location and the implications of this location, we report a new case of malignant fibrous histiocytoma of the soft palate and lateral wall of the oropharynx. The literature on this pathology is reviewed. habitual. A la exploración intraoral se observaba una gran masa exofítica de $7 \mathrm{~cm}$ de diámetro máximo, carnosa, que parecía pediculada a paladar blando y ocupaba la luz de la orofaringe (Fig. 1). No se palpaban adenopatías cervicales. La TC cervicofacial objetivaba una lesión de partes blandas de gran tamaño y bordes bien definidos que parecía originarse en el paladar blando, creciendo exofíticamente y ocupando la luz de la orofaringe (Fig. 2). No se objetivaron adenopatías de características patológicas. El resto de la exploración física y la TC toracoabdominal no objetivaron otras lesiones a distancia. Se realizó una biopsia incisional que reveló una neoplasia fusocelular constituida por una población de células de hábito fibrohistiocitario con un patrón de crecimiento tipo estoriforme, compatible con fibrohistiocitoma maligno (Fig. 3). Dada la obstrucción rápidamente progresiva de la vía aérea superior, el

\section{Clinical case}

We report the case of a 54-year-old man who was seen in our clinic for dysphagia, dyslalia, and a foreign body sensation in the oral cavity of 2 months' evolution. The patient was a regular smoker. Intraoral examination revealed a large, fleshy, exophytic mass, $7 \mathrm{~cm}$ maximum diameter, that appeared to be pediculated from the soft palate and occupied the oropharyngeal lumen (Fig. 1). No cervical lymph nodes were palpated. Cervicofacial CAT disclosed a softtissue lesion of large size and well defined margins that seemed to arise from the soft palate, growing exophytically and occupying the oropharyngeal lumen (Fig. 2). No patho- 
paciente requirió la realización de una traqueostomía previamente a la cirugía definitiva. El paciente fue sometido a cirugía realizándose un abordaje mediante labiomandibulotomía media, exéresis de la lesión con márgenes de seguridad -lo que supuso la resección de la totalidad del paladar blando, pilares amigdalinos y la pared de orofaringe izquierda- y la reconstrucción inmediata con un colgajo fasciocutáneo radial del lado izquierdo (Figs. 4-7). El estudio anatomopatológico de la pieza reveló una neoplasia fusocelular constituida por una población de células de hábito fibrohistiocitario, de núcleos ovalados, pleomórficos y citoplasmas fusiformes, que alternaba con otras de hábito epitelioide, dispuestas formando haces entrecruzados y adoptando en zonas un patrón de crecimiento tipo estoriforme, confirmando así el diagnóstico inicial. Se identificaron frecuentes figuras de mitosis, algunas de ellas atípicas. Las tinciones para vimentina y proteina CD68 fueron positivas. La neoplasia respetaba ampliamente los márgenes de resección quirúrgicos. Dado el gran tamaño de la lesión, fue administrado tratamiento radioterápico complementario. El paciente ha permanecido libre de recidiva local o a distancia hasta el momento actual y presenta un excelente resultado estético y funcional, con deglución y fonación normales.

\section{Discusión}

A raíz de la descripción por O’Brien y Stout del histiocitoma fibroso maligno (HFM) como un tipo histológico independiente de los sarcomas de tejidos blandos, se han publicado grandes series de HFM y se acepta hoy como el sarcoma de tejidos blandos más frecuente de la edad adulta, 2,4-9 siendo también uno de los más frecuentes en el territorio maxilofacial. ${ }^{10,11}$

El fibrohistiocitoma maligno puede presentarse a cualquier edad, aunque es realmente infrecuente antes de los cuarenta años y extremadamente raro en la infancia. Se observa un pico de mayor incidencia en la séptima década y es más frecuente en hombres que en mujeres.2,5-7 Puede localizarse en tejidos blandos y de forma primaria intraósea. Sus localizaciones más frecuentes son la extremidades (60\%) y el retroperitoneo o cavidad abdominal (20\%), siendo menos frecuente en el área maxilofacial.2,4-7,12,13 El tracto nasosinusal es su localización craneofacial más común, siendo otras el

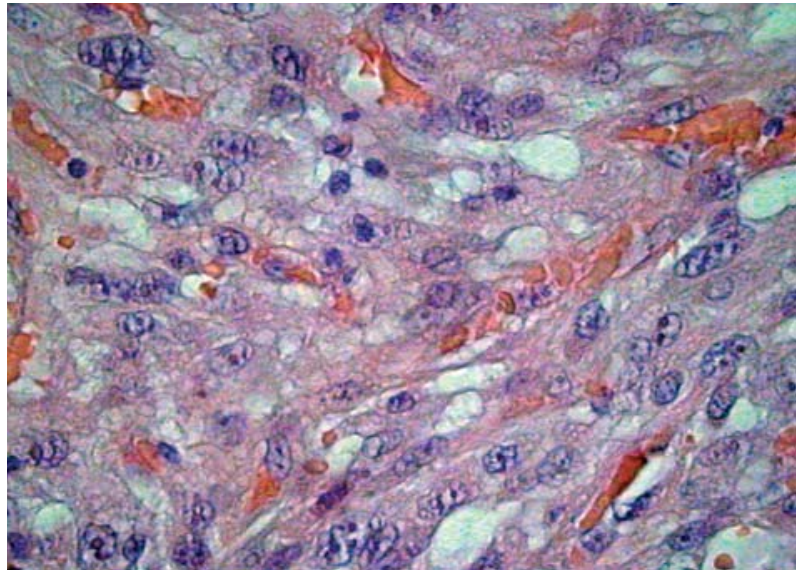

Figura 3. Espécimen histológico mostrando la población tumoral fibrohistocitaria que adopta un patrón estoriforme.

Figure 3. Histologic specimen showing the fibrohistocytic tumor population, which exhibits a storiform pattern.

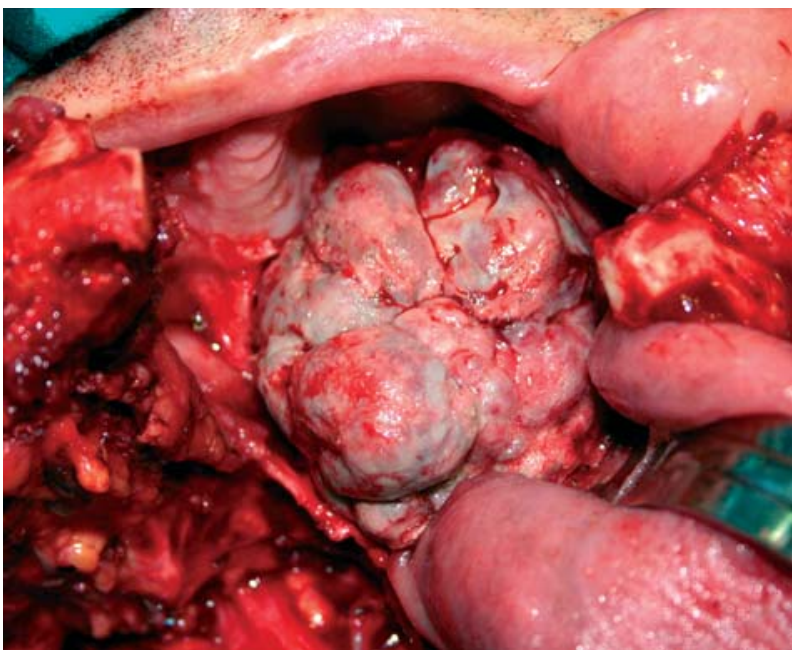

Figura 4. Fotografía intraoperatoria donde se observa la gran blando.

Figure 4. Intraoperative photograph showing a large, vegetative, exophytic tumor arising from the soft palate. logical lymph node enlargement was observed. The rest of the physical examination and thoracoabdominal CAT found no tumoral spread. An incisional biopsy revealed a fusocellular neoplasm constituted by a population of fibrohistiocytic cells with a storiform growth pattern, which was compatible with malignant fibrohistiocytoma (Fig.3). As upper airway obstruction was developing rapidly, the patient required tracheostomy before definitive surgery. He underwent surgery via medial labiomandibulotomy and the lesion was removed with safety margins. This involved resection of the entire soft palate, amygdalar pillars, and the left wall of the oropharynx. The procedure concluded with immediate reconstruction using a left radial fasciocutaneous flap (Figs 4-7). The histopathologic study of the piece revealed a fusocellular neoplasm constituted by a population of cells of fibrohistiocytic appearance with pleomorphic oval nuclei and fusiform cytoplasm, which alternated with cells of epithelioid appearance. They were arrayed forming imbricated bundles and adopting a storiform growth pattern in areas, which confirmed the initial diagnosis. Frequent mitotic figures were identified, some of them atypical. Staining for vimentine and CD68 protein was positive. The neoplasm was removed surgically with ample resection margins. Due to the large size of the lesion, complementary irradiation was given. The patient has remained free of local or distant recurrence until now. The aesthetic and functional results are excellent, with normal swallowing and phonation.

\section{Discussion}

As a result of the description by $\mathrm{O}^{\prime}$ Brien and Stout of 
esqueleto facial, la laringe, tejidos blandos del cuello y las glándulas salivares mayores.3,14 Si su localización en cavidad oral es poco frecuente, 12,14-18 menos aún lo es en la faringe, habiéndose recogido en la literatura científica tan solo 6 casos en esta localización. ${ }^{19-24}$

Macroscópicamente el tumor tiene una apariencia multilobulada, carnosa, grisácea y aunque parece circunscrito, en la mayoría de los casos se encuentran extensiones microscópicas al tejido adyacente. ${ }^{2}$ Microscópicamente, las células neoplásicas adoptan morfologías muy variables, en ocasiones similares a histiocitos y en otras la apariencia es de fibroblastos. El patrón histológico también es altamente variable de unas zonas a otras y entre distintos tumores, habiéndose clasificado en función de su apariencia y la población celular predominante en distintos subtipos: estoriformepleomorfo, mixoide, de células gigantes, inflamatorio y angiomatoide. La forma pleomórfica-estoriforme es la más frecuente y se caracteriza por contener grupos de células neoplásicas fusocelulares en un patrón estoriforme alrededor de vasos, además de células redondeadas similares a histiocitos, frecuentemente exhibiendo cierto grado de pleomorfismo (Fig.3). Este tipo tiende a ser pobremente diferenciado, más frecuentemente grado 2 ó 3 . En la variante mixoide se observan células mesenquimales en un estroma mixoide rico en mucopolisacáridos, también existe cierto grado de pleomorfismo celular, pero en mucho menor grado que en el subtipo anterior; tiene menos tendencia a metastatizar a distancia, observándose un mejor pronóstico. En el subtipo de células gigantes lo peculiar es la presencia de una mezcla de células multinucleadas malignas y benignas y en particular de células gigantes de tipo osteoclástico, asociadas con células estromales que asemejan histiocitos mononucleares con grados variables de anaplasia. La variante inflamatoria se caracteriza por la presencia de abundantes neutrófilos, células plasmáticas, linfocitos y, en ocasiones, células espumosas, en un estroma pobremente colagenizado. El tipo angiomatoide predomina en sujetos menores de 40 años, suele ser de bajo grado y en él se observan áreas de hemorragia con depósito de hemosiderina junto con una población fibrohistiocítica pleomórfica y elevada actividad mitótica. 2,6,7 Nuestro caso corresponde a la variante estoriforme.

Como para otros tipos de sarcomas, se han observado casos de fibrohistiocitomas malignos radioinducidos tras un periodo de laten-

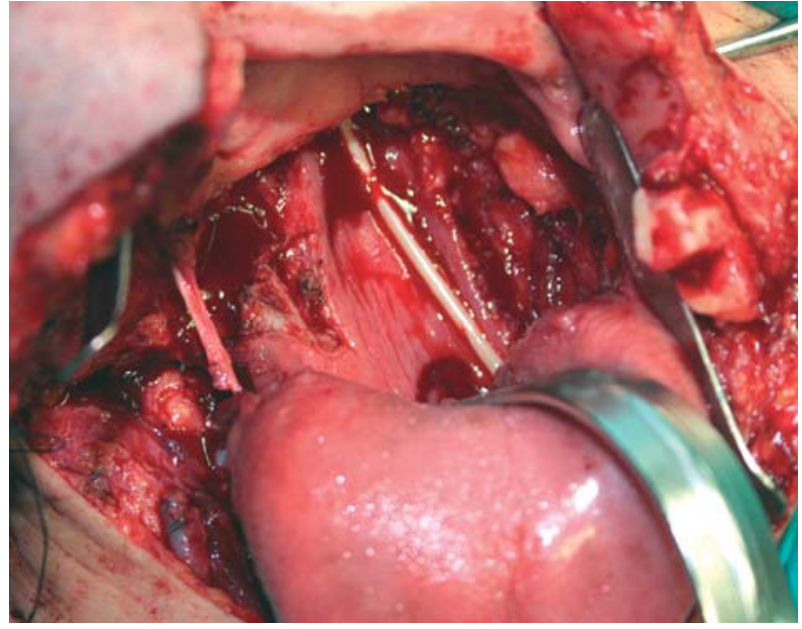

Figura 5. Fotografía intraoperatoria donde se muestra el gran defecto creado tras la resección con márgenes de la tumoración. Figure 5. Intraoperative photograph of the large defect created by wide-margin resection of the tumor.

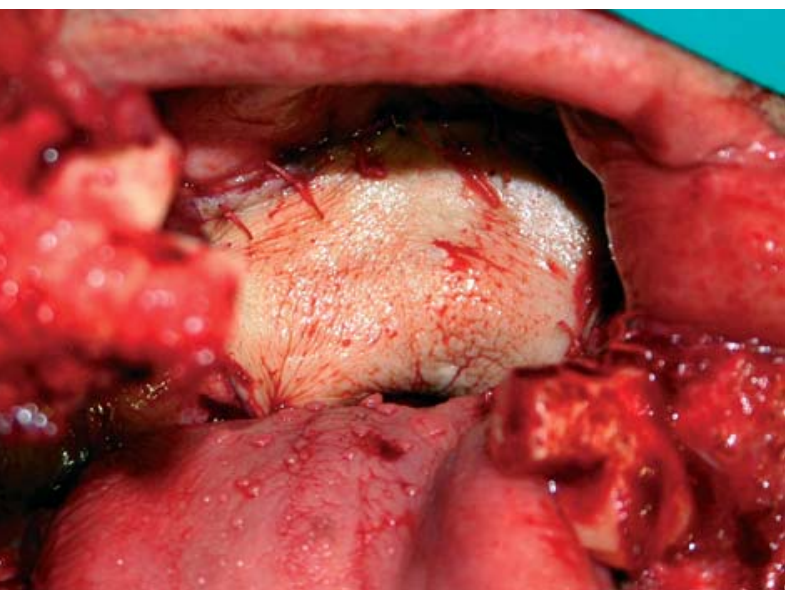

Figura 6. Fotografía intraoperatoria mostrando la reconstrucción del defecto en orofaringe con el colgajo fasciocutáneo radial. Figure 6. Intraoperative photograph showing the reconstruction of the oropharyngeal defect with a radial fasciocutaneous flap. malignant fibrous histiocytoma (MFH) as an independent histologic type of softtissue sarcoma, large series of MFH have been published. Today it is accepted as the most frequent soft-tissue sarcoma in adults2, 4-9 and one of most frequent in the maxillofacial territory. ${ }^{10,11}$

Malignant fibrohistiocytoma may occur at any age, although it is uncommon before the age of 40 years and extremely rare in childhood. A peak incidence is observed in the seventh decade and it is more frequent in men than in women.2, 5-7 It may be located in soft tissues or appear as a primary intraosseous tumor. The most frequent sites are the limbs (60\%) and retroperitoneum or abdominal cavity (20\%), the least common site being the maxillofacial area. ${ }^{2,4-7,12,13}$ The most frequent craniofacial site is the nasosinusal tract; other sites are the facial skeleton, larynx, soft tissues of the neck and major salivary glands. 3,14 While the location in the oral cavity is uncommon,12,14-18 pharyngeal tumors are even rarer. Only 6 cases of malignant fibrous histiocytoma have been reported in the pharynx in the scientific literature. ${ }^{19-24}$

The gross tumor had a gray-colored, fleshy, multilobate appearance. Although it appears circumscribed, in most cases there is microscopic spread to adjacent tissue. ${ }^{2}$ Microscopically, the neoplasm has various morphologies, sometimes similar to histiocytes and other times similar to fibroblasts. The histologic pattern is highly variable from one area to another and between different tumors. It is classified, based on appearance and predominant cell population, into different subtypes: storiform-pleomorphic, myxoid, giant-cell, inflammatory, and angiomatoid. The pleomophic-storiform type is the most common and is characterized as containing groups of spindle-shape neoplastic cells in a storiform pattern around blood vessels, in addition to histiocyte-like round cells that frequently exhibit a certain degree of pleomorphism (Fig.3). This type tends to be poorly differentiat- 
cia variable entre 5 y 45 años. 6,25-28 En 1999 Patel y cols., 25 estudiaron una serie de 10 pacientes con sarcomas de cabeza y cuello radioinducidos, observando que el HFM era el subtipo más frecuente (4/10). En este mismo artículo, realizan una revisión de los sarcomas de cabeza y cuello radioinducidos publicados en la literatura científica hasta ese momento, encontrándose que el diagnóstico más frecuente también fue de HFM (36\%). Pero en lo que respecta a nuestro caso, no se identificó este antecedente.

Este tumor habitualmente se presenta como una masa indolora de crecimiento progresivo, habitualmente de menos de seis meses de evolución. Cuando la tumoración se localiza en cavidades como el abdomen o retroperitoneo, el paciente puede presentar sintomatología de distensión abdominal progresiva, como progresivo aumento del perímetro abdominal, aparición de hernias y varicocele. En los casos intraabdominales y retroperitoneales también se puede observar la presentación conjunta de un síndrome constitucional, aunque en el resto de localizaciones no es una clínica habitual. 2,7 La peculiar localización del caso que presentamos, condicionó una rápida y profusiva obstrucción de la vía aérea, lo que determinó la realización de una traqueostomía previa a la cirugía definitiva.

La extensión metastásica a distancia no es un fenómeno infrecuente, habiéndose cifrado en torno al $40 \%$ de los casos y siendo su localización más típica la pulmonar (80-90\%), seguida de la ósea y hepática. En función de las series, se encontraron extensión a ganglios linfáticos regionales en un 10-32\%.2,3,5,6,29 Respecto al riesgo de metástasis, Le Doussal y cols., ${ }^{6}$ encontraron un aumento de éste en pacientes con grado histológico 3 y un tamaño tumoral mayor de $8 \mathrm{~cm}$. Otros autores hallaron además la profundidad del tumor correlacionada directamente con el porcentaje de metástasis, mientras que el porcentaje de células inflamatorias presentes en la lesión parecía tener un efecto protector frente a éstas. ${ }^{2}$ En nuestro caso el estudio de extensión no mostró metástasis regionales ni a distancia y dado que en general no se considera un tumor con alta linfofilia no se consideró indicada la realización de un vaciamiento cervical profiláctico.

La recurrencia local tiene un gran impacto en la supervivencia. Estudios previos han observado un porcentaje de recidiva del HFM variable entre el 26 y el 51\%.2,5-7,14,29 En un reciente estudio, Sabesan y cols., ${ }^{3}$ encontraron que el porcentaje de recidivas se hallaba directamente relacionado con la amplitud de la resección realizada, siendo para HFM de cabeza y cuello, de un $86 \%$ en el caso de resecciones marginales (con menos de $3 \mathrm{~cm}$ de margen quirúrgico) frente a un $27 \%$ de aquellos donde se había realizado una resección radical. Este estudio apoya los resultados obtenidos por otros autores para HFM en otras localizaciones, como Shinozaki y cols. que observaron una recurrencia local del 100\%, 72\%, 17\% y $0 \%$ anaplasia. The inflammatory variant is characterized by the presence of abundant neutrophils, plasma cells, lymphocytes and, occasionally, foam cells in poorly collagenized stroma. The angiomatoid type predominates in subjects under the age of 40 years. This type usually is low-grade, with areas of bleeding and hemosiderin deposits, together with a pleomorphic fibrohistiocytic population and high mitotic activity.2,6,7 Our case pertained to the storiform variant.

As for other types of sarcomas, radiation-induced cases of malignant fibrohistiocytoma have been observed after a period of latency ranging from 5 to 45 years.6,25-28 In 1999, Patel et al. ${ }^{25}$ studied a series of 10 patients with radiationinduced sarcoma of the head and neck and observed that MFH was the most frequent subtype (4/10). In the same article, they reviewed radiation-induced head and neck sarcomas published in the scientific literature up until that time and found that the most frequent diagnosis was also MFH (36\%). Previous irradiation was not found in our case.

This tumor usually occurs as a painless mass with progressive growth that habitually has a history of less than six months. When the tumor is located in cavities like the abdomen or retroperitoneum, the patient may present symptoms of progressive abdominal distention, such as a progressive increase in abdominal girth and the appearance of hernias and varicoceles. Intraabdominal and retroperitoneal cases may be accompanied by constitutional syndrome, but at other sites it is not a habitual clinical manifestation.2, 7 The special location of the tumor in the case presented here cause rapid and extensive airway obstruction, which made tracheostomy necessary before definitive surgery.

Remote metastatic extension is not uncommon, being found in about $40 \%$ of cases. The most typical location of remote spread is the lung (80-90\%), followed by bone and liver. In different series, regional lymph node involvement 
para resecciones intralesionales, marginales, amplias o amputación, respectivamente. ${ }^{30}$

Existen múltiples factores que parecen influir en la evolución del fibrohistiocitoma maligno. En un estudio sobre 227 casos de HFM, Pezzi y cols., ${ }^{5}$ encontraron que el tamaño de la lesión y su grado histológico fueron los factores pronósticos más importantes. En este trabajo se observó una supervivencia media a los 5 años para tumores menores de $5 \mathrm{~cm}$ de diámetro y de grado intermedio de malignidad del 93\%, mientras que para aquellos mayores de $10 \mathrm{~cm}$ y de alto grado de malignidad, tan solo fue del $41 \%$. En su estudio sobre factores pronósticos para pacientes con HFM localizado, Le Doussal y cols. ${ }^{6}$ encontraron que la supervivencia específica de la enfermedad se hallaba relacionada inversamente y de forma significativa con el estadio, la presencia de enfermedad residual, la profundidad del tumor y la histología no mixoide. También observaron que la radioterapia postoperatoria y los márgenes quirúrgicos libres de infiltración tumoral parecían aumentar el control local de la enfermedad. Sin embargo, otros autores como Kearney y cols., ${ }^{7}$ en un estudio sobre 167 HFM, coinciden en que la profundidad del tumor y su localización parecen afectar a la supervivencia, pero no consideran el tamaño tumoral ni el subtipo histológico como factores de riesgo independientes. También Roser y cols. ${ }^{9}$ encontraron factores como la profundidad del tumor, el grado histológico, el tamaño de la lesión y los subtipos estoriforme-pleomórfico indicativos de peor pronóstico.

Dentro de los sarcomas de cabeza y cuello, el HFM presenta una supervivencia mayor que otros tumores de este mismo grupo, siendo ésta a los 5 años de 50 a 74\% en función de las series.3,5,6,9,29,31 Wanebo y cols., en un estudio sobre 214 sarcomas de cabeza y cueIlo, encontraron que la supervivencia media del HFM a los 5 años era de un $72 \%$, por encima de la supervivencia para otros tipos de sarcomas más agresivos como el angiosarcoma, osteosarcoma y rabdomiosarcoma. ${ }^{31}$

En cuanto al pronóstico de los HFM en cabeza y cuello comparado con aquellos localizados en extremidades y tronco, resulta interesante el estudio de Sabesan y cols., del 2004 sobre 131 pacientes con HFM, 54 en cabeza y cuello y 77 en otras localizaciones. ${ }^{3}$ Estos autores observaron una mayor supervivencia a los 5 años para aquellos HFM localizados en extremidades y tronco (77\% de pacientes vivos a los 5 años y $65 \%$ libres de enfermedad, frente a un $48 \%$ y $41 \%$ respectivamente para aquellos HFM de cabeza y cuello). Por otra parte esto podría explicarse por dos factores: el mayor porcentaje de tumores de alto grado en cabeza y cuello observado en esta serie (78\% frente al 55\%) y el mayor porcentaje de resecciones amplias y radicales realizadas en extremidades $y$ tronco.

El tratamiento de elección es la resección con amplios márgenes, ya que en estos tumores se observa una elevada tendencia a la recidiva local, que parece directamente relacionada con la extensión de la resección, ${ }^{3,}, 30$ y la presencia o ausencia de enfermedad residual. ${ }^{6}$ Dado que no se considera un tumor con gran linfofilia, el vaciamiento cervical profiláctico no está indicado, realizándose disección cervical solo en caso de presencia de adenopatías metastásicas clínica o radiológicamente positivas. Aunque el papel de la radioterapia no ha sido bien establecido, existen estudios como el de Hsu y cols., ${ }^{29}$ sobre 76 pacientes con HFM loca- is found in 10-32\%.2,3,5,6,29 With regard to the risk of metastasis, Le Doussal et al. 6 encountered more metastasis in patients with grade 3 histology and tumor size greater than $8 \mathrm{~cm}$. Other authors find that the depth of the tumor correlates directly with the percentage of metastases; in contrast, the percentage of inflammatory cells present in the lesion seems to have a protective effect against metastasis. ${ }^{2}$ In our case, the study of the extension found no regional or distant metastases and, given that, in general, it is not considered to be a highly lymphophilic tumor, prophylactic removal of cervical lymph nodes is not thought to be indicated.

Local recurrence has a great impact on survival. Previous studies report a MFH recurrence rate ranging from 26 to $51 \% .2,5-7,14,29$ In a recent study, Sabesan et al. 3 find that the recurrence rate is directly related with the extent of resection. For MFH of the head and neck, the recurrence rate is $86 \%$ in marginal resections (with less than $3 \mathrm{~cm}$ of surgical margin) versus $27 \%$ in radical resections. This study supports the results obtained by other authors for MFH in other sites, such as Shinozaki et al., who observed local recurrence in 100\%, 72\%, $17 \%$ and $0 \%$, respectively, of intralesional, marginal, or extensive resections and amputation. ${ }^{30}$

Various factors seem to influence the evolution of malignant fibrohistiocytoma. In a study of 227 cases of MFH, Pezzi et al. 5 found that the size of the lesion and its histologic grade were the most important prognostic factors. In this study, a mean 5-year survival for tumors smaller than $5 \mathrm{~cm}$ in diameter and intermediate grade malignancy of $93 \%$ was observed. For tumors larger than $10 \mathrm{~cm}$ and high-grade malignancy, the 5-year survival was only $41 \%$. In a study of prognostic factors in patients with localized MFH, Le Doussal et al. ${ }^{6}$ found that disease-specific survival was inversely and significantly related with stage, presence of residual disease, tumor depth, and nonmyxoid histology. They also observed that postoperative radiotherapy and surgical margins free of tumoral infiltration seemed to increase local control of the disease. However, other authors like Kearney et al.,7 in a study of $167 \mathrm{MFH}$, agree that tumor depth and location seem to affect survival, but tumor size and histologic subtype are not considered to be independent risk factors. Roser et al. 9 also found factors like tumor depth, histologic grade, lesion size, and storiform-pleomorphic subtype to be indicative of worse prognosis.

Among the sarcomas of the head and neck, MFH presents a longer survival than other tumors of the same group, being $50-74 \%$ at 5 years depending on the series. $3,3,6,9,29,31$ Wanebo et al., ${ }^{31}$ in a study of 214 head and neck sarcomas, found that the mean survival of MFH at 5 years was 72\%, which is higher than the survival for other, more aggressive types of sarcoma, such as angiosarcoma, osteosarco$\mathrm{ma}$, and rhabdomyosarcoma.

With respect to the prognosis of MFH of the head and neck versus the limbs and trunk, the 2004 study of Sabesan et al. ${ }^{3}$ of 131 patients with MFH disclosed 54 in the head 
lizado, donde analizan distintos factores pronósticos (edad, sexo, localización tumoral, estadio, tamaño, profundidad, márgenes quirúrgicos positivos, radioterapia y dosis administrada), encontrando que la administración de radioterapia postoperatoria era el único factor que mejoraba el control local de la enfermedad, aunque sin aumentar el tiempo medio de supervivencia (control local a los 5 años de $85 \%$ para pacientes que habían recibido radioterapia, frente al $44 \%$ de los que no la habían recibido). El papel de la quimioterapia está bien establecido para algunos tipos de sarcomas de partes blandas como el rabdomiosarcoma, osteosarcoma y sarcoma de Ewing, pero permanece controvertido para otro tipo de sarcomas del adulto, como en el caso del HFM. En cuanto a este punto, cabe destacar un metaanálisis publicado por la SMAC (Sarcoma Meta-analysis Collaboration) basado en datos individuales de 1568 pacientes tratados con regímenes quimioterápicos basados en la doxorrubicina. ${ }^{2}$ Encontraron que el tratamiento quimioterápico parecía influir significativamente en las recidivas locales y a distancia, así como aumentar la supervivencia libre de enfermedad en pacientes con sarcomas localizados de tejidos blandos. Por lo tanto hasta ahora no existe consenso en cuanto a la indicación de administrar tratamiento complementario a la cirugía en el HFM. Serían necesarios estudios prospectivos, aleatorizados y randomizados, pero dada la baja incidencia de este tipo de tumores, parecen muy difíciles de llevar a cabo.

\section{Conclusiones}

El fibrohistiocitoma maligno de cabeza y cuello es un tumor agresivo, donde una resección inadecuada se relaciona con un mayor porcentaje de recidivas locales y un peor pronóstico. Por ello, el tratamiento primario de este tipo de tumores debería ser la resección, tan amplia como fuera posible. En caso de aquellos tumores en que su localización o gran tamaño no permitan unos adecuados márgenes, la radioterapia postoperatoria podría permitir un mayor control local de la enfermedad.

El colgajo fasciocutáneo radial ofrece excelentes resultados en la reconstrucción de grandes defectos de la orofaringe, incluyendo el paladar blando.

\section{BIBLIOGRAFÍA}

1. O'Brien JE, Stout AP. Malignant fibrous xantomas. Cancer 1964;17:1445-555.

2. Weiss SW, Enzinger FM. Malignant fibrous histiocytoma. An analysis of 200 cases. Cancer 1978;41:2250-66.

3. Sabesan T, Xuexi W. Malignant fibrous histiocytoma: outcome of tumours in the head and neck compared with those in the trunk and extremities. Br J Oral Maxillofac Surg 2006;44:209-12.

4. Gibbs JF, Huang PP, Lee RJ, y cols. Malignant fibrous histiocytoma: an institucional review. Cancer Invest 2001;19:23-7.

5. Pezzi ME, Rawling MS, Esgro JJ, y cols. Prognostic factors in 227 patients with malignant fibrous histiocytoma. Cancer 1992;69:2098.

6. Le Doussal V, Coindre J-M, Leroux A, y cols: Prognostic factors for patients with localized primary malignant fibrous histiocytoma. A multicenter study of 216 patients with multivariate analysis. Cancer 1996;77:1823. and neck and 77 in other locations. These authors reported a longer 5-year survival for MFH of the limbs and trunk $(77 \%$ of patients alive at 5 years and $65 \%$ disease-free versus $48 \%$ and $41 \%$, respectively, for MFH of the head and neck). This could be explained by two factors: a larger percentage of high-grade tumors of the head and neck in this series (78\% vs. 55\%) and a higher percentage of extended and radical resections in the limbs and trunk.

The treatment of choice is resection with wide margins because these tumors have a strong high tendency to local recurrence. This seems to be directly related with the extension of the resection 3,30 and presence or absence of residual disease. ${ }^{6} \mathrm{MFH}$ is not considered a highly lymphopilic tumor, so prophylactic cervical resection is not indicated. Cervical dissection is contemplated only in the presence of clinically or radiologically positive metastatic lymph nodes. Although the role of irradiation is not well established, different prognostic factors (age, sex, tumor location, stage, size, depth, positive surgical margins, irradiation and the dose administered) have been analyzed in studies like that of Hsu et al. ${ }^{29}$ on 76 patients with localized MFH. These authors found that postoperative irradiation was the only factor that improved local disease control, although without increasing mean survival time (local control at 5 years of $85 \%$ for irradiated patients vs. $44 \%$ of non-irradiated patients). The role of chemotherapy is well established for some types of soft-tissue sarcoma, like rhabdomyosarcoma, osteosarcoma and Ewing's sarcoma. However, this factor is debated in other sarcomas of adults, as in the case of MFH. A meta-analysis published by the SMAC (Sarcoma MetaAnalysis Collaboration) on the individual data of 1568 patients treated with doxorubicin-based chemotherapy schedules is noteworthy regarding this point. ${ }^{32}$ They found that chemotherapy treatment apparently had a significant influence on local and distant recurrence and that it increased the disease-free survival of patients with localized soft-tissue sarcoma. Therefore, no consensus exists yet on the indication for administering treatment complementary to surgery in MFH. Prospective randomized studies are needed, but given the low incidence of this type of tumor, they would be very difficult to conduct.

\section{Conclusions}

Malignant fibrohistiocytoma of the head and neck is an aggressive tumor. Inadequate resection is related to a higher local recurrence rate and worse prognosis. For that reason, the primary treatment of this type of tumor is resection as extensive as possible. In case of tumors in which adequate margins are not possible due to their location or large size, postoperative irradiation may improve control of the disease.

Radial fasciocutaneous flaps produce excellent results in the reconstruction of large defects of the oropharynx, including the palate. 
7. Kearney MM, Soule EH, Ivins JC. Malignant fibrous histiocytoma. A retrospective study of 167 cases. Cancer 1980;45:167.

8. Markhede G, Angervall L, Sterner B. A multivariate analysis of the prognosis after surgical treatment of malignant soft tissue tumours. Cancer 1982;49:1721-33.

9. Rööser B, Willen H, Gustafson $P, y$ cols. Malignant fibrous histiocytoma of soft tissues. A population-based epidemiologic and prognostic study of 137 patients. Cancer 1991;67:499-505.

10. Huber GF, Matthews TW, Dort JC. Soft-tissue sarcomas of the head and neck: a retrospective analysis of the Alberta experience 1974 to 1999. Laryngoscope 2006;116:780-5.

11. Sturgis EM, Potter BO. Sarcomas of the head and neck region. Curr Opin Oncol 2003;15:239-52.

12. Rapidis AD, Andressakis DD, Lagogiannis GA, Douzinas EE. Malignant fibrous histiocytoma of the tongue: review of the literature and report of a case. J Oral Maxillofac Surg 2005;63:546-50.

13. Kanazawa $H$, Watanabe $T$, Kasamatsu A. Primary malignant fibrous histiocytoma of the mandible: review of literature and report of a case. J Oral Maxillofac Surg 2003;61:1224-7.

14. Barnes L, Kanbour A. Malignant fibrous histiocytoma of the head and neck: a report of 12 cases. Arch Otolaryngol Head Surg Neck 1988;114:1149-56.

15. Bras J, Batsakis JG, Luna MA. Malignant fibrous histiocytoma of the oral tissues. Oral Surg 1987;64;57.

16. Chen YK, Lin LM, Lin CC. Malignant fibrous histiocytoma of the tongue. J Laryngol Otol 2001;115:763-5.

17. McMillan MD, Smillie AC, Ferguson JW. Malignant fibrous histiocytoma of the tongue: report of a case and ultraestructural observations. J Oral Pathol 1986;15:255.

18. Manni JJ, Van Den Broek P, Van Haelst UJ, y cols. Malignant fibrous histiocytoma of the tongue. J Maxillofac Surg 1986;14:103.

19. Kinishi M, Amatsu M. Malignant fibrous histiocytoma of the hypopharynx ORL. J Otorhinolaryngol Relat Spec 1990;52:47-50.
20. Murakami M, Akiyama Y, Tei G, Shinomiya T. Malignant Fibrous Histiocytoma in the hypopharynx; A case report. Acta Otalgica (Kyoto) 1995;88:623-8.

21. Bonnin P, Lallemant JG. Malignant histiocytofibroma. A propos of 3 cases of cervicofacial localization. Ann Otolaryngol Chir Cervicofac 1995; 112:336-44.

22. Mevio E, Sbrocca M, Malignant fibrous histiocytoma of the pharynx. Acta Otorhinolaryngol Belg 2003;57:79-81.

23. Nakamizo M, Yokoshima K, Malignant fibrous histiocytoma of the hypopharynx: a case report in a young adult. I Nippon Med Sch 2004;71:301-5.

24. Lakhani P, Rubesin SE, Zhang PJ. Malignant fibrous histiocytoma of the pharynx. AJR Am J Roentgenol 2005;184(3 Suppl):S12-3.

25. Patel SG, See AC, Williamson PA, Archer DJ, Evans PH. Radiation induced sarcoma of the head and neck. Head Neck 1999;21:346-54.

26. Wiesmilleer K, Barth TF. Early radiation-induced malignant fibrous histiocytoma of the oral cavity. J Laryngol Otol 2003;117:224-6.

27. Haberal I, Samim E. Radiation-induced malignant fibrous histiocytoma of the neck in a patient with laryngeal carcinoma. Am J Otolaryngol 2001;22:146-9.

28. Guney E, Yigitbasi OG. Postirradiation malignant fibrous histiocytoma of the larynx: a case report. Am J Otolaryngol 2002;23:293-6.

29. Hsu HC, Huang EY, Wang CJ. Treatment results and prognostic factors in patients with malignant fibrous histiocytoma. Acta Oncol 2004;43:530-5.

30. Shinozaki T, Kato K, Watanabe H, Yanagawa T, Ahmed AR, Takagishi K. Discriminant analysis of prognostic factors for malignant fibrous histiocytoma in soft tissue. J Orthop Sci 2001;6:339-42.

31. Wanebo HJ, Koness RJ. Head and neck sarcoma: report of the head and neck sarcoma registry. Society of Head and Neck Surgeons Committee on Research. Head neck 1992;14:1-7.

32. Sarcoma Meta-analysis Collaboration (SMAC) Meta-analysis Group. Adjunvant chemotherapy for localized respectable soft tissue sarcoma in adults. Cochrane Database Syst Rev 2000;4:CD001419. 